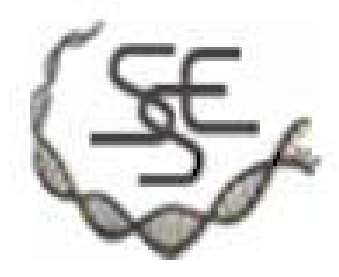

Delayed Maturation, Neoteny, and Social System Differences in Two Manakins of the Genus Chiroxiphia

Author(s): Mercedes S. Foster

Reviewed work(s):

Source: Evolution, Vol. 41, No. 3 (May, 1987), pp. 547-558

Published by: Society for the Study of Evolution

Stable URL: http://www.jstor.org/stable/2409256

Accessed: 05/01/2013 07:49

Your use of the JSTOR archive indicates your acceptance of the Terms \& Conditions of Use, available at http://www.jstor.org/page/info/about/policies/terms.jsp

JSTOR is a not-for-profit service that helps scholars, researchers, and students discover, use, and build upon a wide range of content in a trusted digital archive. We use information technology and tools to increase productivity and facilitate new forms of scholarship. For more information about JSTOR, please contact support@ jstor.org. 


\title{
DELAYED MATURATION, NEOTENY, AND SOCIAL SYSTEM DIFFERENCES IN TWO MANAKINS OF THE GENUS CHIROXIPHIA
}

\author{
MERCEDES S. Foster \\ U. S. Fish and Wildlife Service, National Museum of Natural History, \\ Washington, DC 20560
}

\begin{abstract}
Long-tailed manakins (Chiroxiphia linearis) and swallow-tailed manakins (C. caudata) are closely related, sexually dichromatic, lek-breeding species in which male mating success is highly skewed. Males of both species delay plumage maturation. Before reaching the definitive state, they wear a sequence of feather coats less conspicuous than that of the adult. Nondefinitive plumages probably enhance male survival in the two species; in $C$. caudata they may also enhance breeding success of young males, who may be fully reproductively mature their first year. In $C$. linearis testicular development is retarded along with that of plumage, although males may be physiologically capable of breeding prior to the acquisition of the definitive plumage. This difference probably reflects differences in the social systems of the two species. Five hypotheses have been proposed to explain the evolution of delayed plumage maturation. The sexual-selection, crypticbreeder, and winter-adaptation hypotheses suggest that it functions primarily to enhance survival of young males. The juvenile- and female-mimicry hypotheses emphasize enhancement of immediate mating success. Support is provided for all but the female-mimicry hypothesis; it is argued that data are more consistent with juvenile mimicry and a neotenic origin of nondefinitive plumages.
\end{abstract}

Received March 24, 1986. Accepted November 20, 1986

Delayed maturation in birds is most frequently observed among males of species in which competition for mates is severe and young have a low probability of reproductive success (Lack, 1954; Ashmole, 1963; Selander, 1965; Rohwer, 1978; Rohwer et al., 1980). It generally is manifest as delayed acquisition of the definitive (and usually brightly colored) adult plumage, relative to timing of its acquisition in closely related forms, although size, feather shape, and behavior may also change with age (Selander, 1958; Foster, unpubl.). Four hypotheses have been proposed to explain the evolution of delayed maturation, and a fifth is proposed here.

Three of the hypotheses suggest that this phenomenon enhances survival. According to the "sexual-selection hypothesis," selection is likely to favor delayed maturation if costs associated with definitive plumages, sexual maturity, and competition for territories and matings are significant relative to the probability of mating success (Selander, 1965, 1972; Rohwer et al., 1980; [="cryptic hypothesis" of] Rohwer et al., 1983). By delaying breeding and acquisition of overt secondary sexual characteristics, young males enhance survival (in part through increased crypsis) and lifetime reproductive output (Wittenberger, 1978; Proctor-Gray and Holmes, 1981).

The "cryptic-breeder hypothesis" also predicts a delay in plumage maturation to increase crypsis but suggests that young birds should be sexually mature and breed whenever possible (Proctor-Gray and Holmes, 1981). Because inexperienced birds are unable to compete with adults for quality territories regardless of plumage form, bright plumage is of no benefit. (This assumes that bright plumage does not function in mate acquisition.) Young males occupy lower quality territories than do older males and thus are less successful at acquiring mates.

The "winter-adaptation hypothesis" (Rohwer et al., 1983), unlike the other two, focuses on enhanced survival on the wintering ground. It suggests that birds in nondefinitive plumages are more readily tolerated by higher ranking individuals and thus increase foraging efficiency or improve access to food or flock feeding territories (Ewald and Rohwer, 1980; Rohwer and Ewald, 1981).

In contrast, two enhanced-breeding hypotheses propose that delayed maturation, which is confined to somatic features, allows young males to increase the probability of breeding their first (or second) year. Roh- 
wer et al.'s (1980) “female-mimicry hypothesis" suggests that young males wear a female-type plumage and, thereby, deceive older males. By exploiting the latter's tendency to tolerate females, they gain access to resources needed to attract a mate or to information that will help them to acquire such resources in future years (Rohwer, 1983).

According to the "juvenile-mimicry hypothesis" proposed in this paper, somatic development is delayed relative to sexual maturity, but juvenile rather than female characteristics are retained in the young (but sexually mature) adults. Decreased aggressiveness of adult males toward young males is a manifestation of the former's tolerance of young birds. Here, nondefinitive plumages are signals of age, rather than of sex, but are deceitful in misrepresenting the preparedness of the birds to breed. Young birds thus gain access to breeding sites and females and increase their probability of mating. In this case, neoteny, the retardation of somatic development relative to sexual maturation, provides a mechanism through which the nondefinitive male plumages may originate. The changes observed are clearly heterochronic (i.e., timing of development of one organ system relative to another differs in the ontogenies of ancestral and descendant organisms). Likewise, despite early reports to the contrary (Gould, $1977 \mathrm{p}$. 346 ), neoteny is probably fairly widespread in birds (Wright and Wright, 1944; Selander and Hauser, 1965; Lawton and Lawton, 1986).

In this paper, I report on reproductive and somatic development in males of two closely related, highly sexually dichromatic species of manakins in which competition for females is severe and male mating success highly skewed (Foster, 1977a, 1981). Males of both species wear a sequence of nondefinitive plumages. In the swallowtailed manakin (Chiroxiphia caudata), males may be fully reproductively mature their first year, with plumage development retarded relative to development of the testes and reproductive behavior. In the long-tailed manakin (C. linearis), in contrast, degree of testicular development generally corresponds to plumage stage, although individuals are reproductively mature prior to ac- quisition of the definitive plumage. Females of both species breed during their first year (Foster, 1976, unpubl.).

Both developmental stages and the corresponding absolute ages are known for these species, and the form of heterochrony in each can be described. Reproductive and plumage differences between them can be examined in light of differences in their social systems, and hypotheses regarding the evolution of delayed maturation evaluated.

\section{MATERIALS AND METHODS}

I studied the reproductive behavior and social interactions of individuals in a colorbanded population of $C$. linearis (Foster, 1976, 1977a, unpubl.) at the Enrique Jiménez Nuñez Experiment Station, Guanacaste Province, Costa Rica, and a colorbanded population of $C$. caudata (Foster, 1981, 1985, unpubl.) at El Tirol, Department of Itapúa, Paraguay. Methods, habitat descriptions, and dates of most observation periods are given in earlier publications (Foster, 1976, 1977a, 1981). Additional observations were made from 13 April-1 May 1977 in Costa Rica, and from 18 September-20 October 1981, 19 September-3 October 1982, and 8-22 May and 2-26 October 1983, in Paraguay.

Plumage characteristics of individuals that were netted were recorded. In addition, specimens of both species in the following museums were examined for plumage, molt, and reproductive data: American Museum of Natural History, Academy of Natural Sciences (Philadelphia), Carnegie Museum of Natural History, Donald R. Dickey Collection (University of California, Los Angeles), Field Museum of Natural History, Louisiana State University Museum of Zoology, Moore Laboratory of Occidental College, Museum of Vertebrate Zoology (University of California, Berkeley), Natural History Museum of Los Angeles Co., National Museum of Natural History, and Western Foundation of Vertebrate Zoology.

In the field, 151 laparotomies (C. linearis, $N=145 ; C$. caudata, $N=6$ ) were performed to determine sex or degree of gonadal development. Specimens of both $C$. linearis $(N=72$ ôे $)$ and $C$. caudata $(N=$ 23 ổ) were collected. Testes were measured, and many ( $C$. linearis, $N=40 ; C$. caudata, 
$N=14$ ) were fixed in $10 \%$ buffered formalin or Bouin's solution for histological analysis. Preserved testes were embedded in paraffin, sectioned at 6 or $7 \mu \mathrm{m}$, stained with hematoxylin and eosin, and staged according to Payne (1969). Testis volumes were estimated using the formula for the volume of an ellipsoid, $v=\frac{4}{3} \pi a v^{2}$, where $a=$ half the testis length and $b=$ its greatest radius. All samples whose means were compared statistically were first tested for homoscedasticity (Sokal and Rohlf, 1969 pp. 186, 371). Means of samples that were homoscedastic were compared using analysis of variance. Means of samples that were not homoscedastic were compared with two- and threesample approximate tests of equality of means when variances are heterogeneous (Sokal and Rohlf, 1969 pp. 374, 372, respectively).

For $C$. caudata, numbers and types of agonistic interactions between variously plumaged males at leks were recorded. The categories of interaction used, listed in decreasing order according to my estimates of potential costs from injury or energy expenditure are as follows:

1) Physical contact: one male flies directly at another in an attempt to displace him, but the perched bird fails to yield and is knocked from the perch. Occasionally, one bird pecks another.

2) Fly-at display: this ritualized display determines or reinforces male rank in the linear dominance hierarchy. In it, two males alternately fly up and toward one another, giving a buzzy call. A bout includes from a few to more than 75 flights, and several bouts may be given. The bout ends with one male (defined as the dominant) hovering with rapidly beating wings in front of the second bird, which cowers in a submissive posture.

3) Chase: one bird chases another through the vegetation for a few seconds.

4) Supplanting: one male flies at another, which moves to a different perch.

5) Threat/ignore: a male ignores or only glances at another male that challenges him (no obvious postures are involved); the challenger veers off and lands elsewhere. The form the attempted interaction may have taken cannot be pre- dicted since chases, supplantings, and fly-at displays are initiated in similar ways.

\section{RESULTS \\ Chiroxiphia caudata}

Plumage Characteristics. - The molts and plumages of this species are treated in detail elsewhere (Foster, unpubl.); data for males are summarized here only briefly (Table 1). Juvenile swallow-tailed manakins are all green. With the postjuvenile molt, they replace all body feathers, retaining a green body plumage. This is the definitive plumage of females (i.e., all subsequent feather coats are the same), and it is the first-year plumage of males. Males acquire a bright orangish red crown at this time; some also acquire a black mask or face. Birds carry this plumage for approximately one year, undergoing a complete molt following their first breeding season. The predefinitive male plumage acquired includes an orangish red crown and otherwise black head; the body and tail are covered with variable proportions of blue, green, or blue and green feathers. The wings are a mixture of black and green. The plumage appears intermediate between the first-year and definitive plumages. After a year, the birds molt into a plumage indistinguishable in the field from the definitive one (Foster, unpubl.), with black head and wings, orangish red crown, and blue body.

Reproductive Competence. - The breeding season in southern Paraguay extends approximately from September to mid-January. Testes are enlarged or enlarging in September, and males occupy leks and perform reproductive displays. With the onset of molt in January, the testes begin to regress.

Testicular volumes of males in definitive, predefinitive, and first-year plumages do not differ significantly when considered as a group $\left(F^{\prime}=4.746\right.$, d.f. $=2,8, P>0.10$; Table 2). Nevertheless, the average testis volume of first-year males is distinctly smaller than that of adults. There is no indication that timing and duration of testis recrudescence differ among age groups either, although sample sizes are small. Testes examined histologically ranged in 
TABLE 1. Approximate timing of molts, and plumage characteristics of male Chiroxiphia.

\begin{tabular}{|c|c|c|}
\hline & C. caudata & C. linearis \\
\hline 0 months & $\begin{array}{l}\text { (Hatching) } \\
\text { Juvenile: all green }\end{array}$ & $\begin{array}{l}\text { (Hatching) } \\
\text { Juvenile: all green }\end{array}$ \\
\hline 3 months & $\begin{array}{l}\text { (Postjuvenile Molt) } \\
\text { Immature/first-year: green with orange-red } \\
\text { crown, with or without black mask or } \\
\text { hood }\end{array}$ & $\begin{array}{l}\text { (Postjuvenile Molt) } \\
\text { Immature: green, with or without a red } \\
\text { crown }\end{array}$ \\
\hline 10 months & Immature/first-year & $\begin{array}{l}\text { (Prenuptial Molt) } \\
\text { First-year: green with red crown, with or } \\
\quad \text { without black mask or hood }\end{array}$ \\
\hline 15 months & $\begin{array}{l}\text { (First Annual Molt) } \\
\text { Predefinitive: mixture of green, blue, and } \\
\text { black with orange-red crown }\end{array}$ & $\begin{array}{l}\text { (First Annual Molt) } \\
\text { Predefinitive I: } 2 / 3 \text { green, } 1 / 3 \text { blue and black } \\
\text { with red crown }\end{array}$ \\
\hline 27 months & $\begin{array}{l}\text { (Second Annual Molt) } \\
\text { Definitive: blue and black with orange-red } \\
\text { crown }\end{array}$ & $\begin{array}{l}\text { (Second Annual Molt) } \\
\text { Predefinitive II: } 1 / 3 \text { green, } 2 / 3 \text { blue and black } \\
\text { with red crown }\end{array}$ \\
\hline 39 months & $\begin{array}{l}\text { (Third Annual Molt) } \\
\text { Definitive }\end{array}$ & $\begin{array}{l}\text { (Third Annual Molt) } \\
\text { Definitive: blue and black with red crown }\end{array}$ \\
\hline
\end{tabular}

volume from $23.56 \mathrm{~mm}^{3}(5 \times 3 \mathrm{~mm})$ to $68.92 \mathrm{~mm}^{3}$. All were reproductively mature (Table 2), showing free sperm in the lumina of the seminiferous tubules.

Males also must be able to perform for females the elaborate precopulatory displays characteristic of the species (Foster, 1981). Males of all age classes appear to display equally well.

Male-Male Interactions in the Absence of Females.-Generally, first-year birds were ignored by older individuals. In only 11 of 207 interactions recorded was one participant a first-year male; the other participant in seven instances was an adult and in four a predefinitively plumaged bird. Interactions of predefinitively plumaged birds are more difficult to interpret. Data from one arena indicate that birds of this age interact with definitively plumaged individuals at rates comparable to those at which the latter interact among themselves (Table 3). However, one subadult and the adult directly above him in the hierarchy interacted extensively, perhaps because their relative ranks were not as well defined as those of other birds in the group. I have no quantitative data on the degree to which predefinitively plumaged birds interact with each other.

Although numbers of interactions are similar (Table 3 ), the proportions of different types of agonistic interactions occurring when two definitively plumaged males interacted versus when definitively and predefinitively plumaged individuals interacted differ significantly $\left(X^{2}=31.0\right.$, d.f. $=4$, $P<0.005$; Table 4). More than half the interactions in the former case involved costly activities (physical contact, fly-at displays, chases), whereas in the latter case, only about a quarter did.

These differences do not result simply from young males initiating less costly activities. The initiator was known in 108 of the 121 cases recorded; in 86 (ca. 80\%) of these it was the adult-plumaged individual. Likewise, in 105 (ca. 90\%) of the 117 interactions in which one male was clearly dominant over the other, the victor was the definitively plumaged male. In 10 of the 22 instances in which a predefinitively plumaged bird initiated an interaction, he supplanted an adult. In the other 12 , he tried to interact with the adult but was ignored.

\section{Chiroxiphia linearis}

Plumage Characteristics. - Juvenile longtailed manakins and definitively plumaged females are also varying shades of green (Foster, unpubl.; Table 1). Males acquire a red crown of varied extent with the postjuvenile molt or the prenuptial molt prior to their first breeding season. Again, a black mask or hood may be present. Following both their first and second breeding seasons, 
TABLE 2. Testis development of male Chiroxiphia caudata and C. linearis in different plumage stages during their respective breeding seasons. (Data from birds in heavy molt are not included.) Testes with free sperm in the lumina of the seminiferous tubules are considered to be reproductive.

\begin{tabular}{|c|c|c|c|c|}
\hline \multirow{2}{*}{$\begin{array}{c}\text { Plumage } \\
\text { (Breeding season) }\end{array}$} & \multicolumn{3}{|c|}{ Testis volume $\left(\mathrm{mm}^{3}\right)$} & \multirow{2}{*}{$\begin{array}{c}\text { Number } \\
\text { reproductive } \\
\text { (number examined }\end{array}$} \\
\hline & Range & $\bar{x} \pm \mathrm{SD}$ & $N$ & \\
\hline \multicolumn{5}{|c|}{ C. caudata: 1 September to 15 January } \\
\hline First-year (1st) & $10.5-50.3$ & $35.7 \pm 14.65$ & 6 & $4(4)$ \\
\hline Predefinitive (2nd) & $23.6-91.6$ & $52.0 \pm 22.33$ & 6 & $2(2)$ \\
\hline Definitive (3rd) & $44.9-68.9$ & $56.4 \pm 8.59$ & 12 & $5(5)$ \\
\hline \multicolumn{5}{|c|}{ C. linearis: 1 March to 31 August } \\
\hline First-year (1st) & $0.2-28.9$ & $6.34 \pm 7.06$ & 18 & $6(8)$ \\
\hline Predefinitive I (2nd) & $1.1-23.6$ & $9.82 \pm 7.50$ & 9 & $3(3)$ \\
\hline Predefinitive II (3rd) & $4.1-23.6$ & $13.36 \pm 7.40$ & 9 & $3(4)$ \\
\hline Definitive (4th) & $7.3-104.7$ & $29.30 \pm 16.16$ & 60 & $18(18)$ \\
\hline
\end{tabular}

the birds undergo complete molts and acquire predefinitive plumages in which the back is a mixture of green and blue. The flight feathers and rest of the body are a mixture of green and black, with the exception of the head, which is black with a red crown. The proportion of green in the first predefinitive plumage (I) is substantially greater than that in the second predefinitive plumage (II). Following the third annual molt, the birds acquire a definitive plumage in which the back feathers are blue, the crown red, and the rest of the body black.

Reproductive Competence.-Long-tailed manakin males in Guanacaste may begin displaying in early March and continue until the first of September. Testis volumes are highly variable, and mean sizes for different age/plumage groups (Table 2) differ significantly $\left(F^{\prime}=24.639\right.$, d.f. $\left.=3,25, P<0.002\right)$. Testis volumes of birds in nondefinitive plumages do not differ significantly from each other $(F=2.860, d . f .=2,33, P>$ $0.05)$, but the combined mean $(\bar{x}=8.963$, $N=36$ ), differs significantly from the mean testis volume of adults $\left(t_{s}{ }^{\prime}=-8.323, d . f\right.$. $=$ $35,59, P<0.001)$. The testis volumes of birds in definitive plumage averaged ca. 2.2 to 4.6 times as large as those of younger males and reached a considerably larger maximum size. Surprisingly, all testes sectioned (Table 2) that exceeded a volume of ca. $8.38 \mathrm{~mm}^{3}(4 \times 2 \mathrm{~mm})$ contained free sperm in the lumina of the seminiferous tubules. Only two of five testes sectioned that had volumes between 3.53 and $6.28 \mathrm{~mm}^{3}$ were active. It is also evident that among birds that are reproductive (testis volume $>8.38 \mathrm{~mm}^{3}$ ), testes of older individuals mature earlier and regress later than do those of birds in younger age classes (Table 5).

Long-tailed manakin males normally do not occupy courts as members of male pairs until they carry the definitive plumage, with the exception of occasional individuals in predefinitive plumage II (Foster, 1977a). On the few occasions on which I did see subadult birds display, they seemed to perform in a manner indistinguishable from that of defintively plumaged males. However, birds in predefinitive I plumage may be less adept than older males at attracting mates. They make the toledo call which, given synchronously with same age or older males, is used

TABLE 3. Numbers of interactions observed among definitively and predefinitively plumaged males of Chiroxiphia caudata occupying the same arena.

\begin{tabular}{lccccc}
\hline \hline Rank/plumage & A/def. & B/def. & C/def. & D/predef. & E/first-year \\
\hline A/Def. & - & 4 & 15 & 10 & 3 \\
B/Def. & & - & 19 & 17 & 0 \\
C/Def. & & & - & 0 & 04 \\
D/Predef. & & & - & 0 \\
\hline
\end{tabular}


TABLE 4. Proportions of different agonistic behaviors used in interactions involving two definitively plumaged males or one definitively plumaged and one predefinitively plumaged male of Chiroxiphia caudata.

\begin{tabular}{cccccc}
\hline \hline & \multicolumn{5}{c}{ Aggressive behavior } \\
\cline { 2 - 6 } Male plumages & $\begin{array}{c}\text { Physical } \\
\text { contact }\end{array}$ & $\begin{array}{c}\text { Fly-at } \\
\text { display }\end{array}$ & Chase & Supplant & $\begin{array}{c}\text { Threat/ } \\
\text { ignore }\end{array}$ \\
\hline $\begin{array}{c}\text { Def./def. } \\
(N=75)\end{array}$ & 0.053 & 0.360 & 0.147 & 0.240 & 0.200 \\
$\begin{array}{c}\text { Def./predef. } \\
(N=121)\end{array}$ & 0.008 & 0.124 & 0.140 & 0.612 & 0.116 \\
\hline
\end{tabular}

to attract mates (Foster, 1977a), but the calls of some of these individuals sound distinctly "off key."

\section{DisCUSSION \\ Enhanced Breeding}

Chiroxiphia caudata. - The effects of predefinitive plumages on reproduction in Chiroxiphia can be evaluated only in the context of the social systems of each species. The swallow-tailed manakin has a modified type of lek social system in which groups of 4-10 males congregate at traditional sites to display for and copulate with females (Foster, 1981). Group composition is relatively stable within and between years, and males may join a group the year following hatching. An age- and plumage-related linear dominance hierarchy is established in the group by means of male-male aggressive interactions that take place in the absence of females (Foster, 1981). All males in the group are tolerated anywhere in the area, including on the perch used for courtship display and copulation, unless a female is present. In that case, the two top-ranking males present display for her. Nearly always these are the alpha and beta males in the hierarchy. Following this joint display, the alpha performs a solo display for the female and then copulates.
Despite this scenario, presence at a court provides low-ranking males, including those in nondefinitive plumages, with access to display sites, females, and the possibility of mating. On several occasions, I observed predefinitively plumaged males display for females. The females always responded with expected movements and postures and were visibly excited. In all instances, however, the alpha male returned to the court and displaced the subordinate male before copulation occurred. I never observed a male in first-year plumage perform a solo precopulatory display for a female. I interpret these observations to mean that females are receptive to mating with males in the predefinitive plumage, if not the first-year plumage, so selection should favor early sexual maturation. Presumably, a female follows a "default strategy" (Beehler and Foster, unpubl.), choosing a group of males, but mating with the most dominant one present at the moment, regardless of his rank in the group. Ultimately, the male with whom the female mates is determined by male-male interactions. Nearly always this will be the most dominant (and oldest) individual in the hierarchy, but during absences of high-ranking males, those of lesser status also may have the opportunity to breed. This suggests that male color pattern is not an epigamic character in this species, but is determined by intrasex agonistic, sexual selection.

Presence on the display court probably enhances breeding for young males in other ways, as well. By establishing tenure at a lek, they may gain in terms of future site dominance (Foster, 1981). They can closely observe and sometimes participate in courtship and dominance interactions and may learn details and tactics of display behavior.

Delayed plumage maturation may enhance breeding opportunities by reducing

TABLE 5. Percentage of Chiroxiphia linearis males in different plumage stages with testes $8.38 \mathrm{~mm}^{3}$ or greater in volume, in different months.

\begin{tabular}{|c|c|c|c|c|c|c|}
\hline \multirow[b]{2}{*}{ Plumage } & \multicolumn{6}{|c|}{ Percentage (total number examined) } \\
\hline & March & April & May & June & July & August \\
\hline First-year & $0(3)$ & $25(8)$ & $67(6)$ & - & $0(5)$ & $0(2)$ \\
\hline Predefinitive I & $25(4)$ & $67(3)$ & $100(2)$ & $0(1)$ & $0(1)$ & - \\
\hline Predefinitive II & $67(3)$ & $75(4)$ & $100(2)$ & - & $0(1)$ & - \\
\hline Definitive & $100(9)$ & $100(15)$ & $100(15)$ & $100(5)$ & $73(11)$ & $60(15)$ \\
\hline
\end{tabular}


their costs. Definitively plumaged males of caudata are more tolerant of subordinates in first-year or predefinitive plumage than they are of subordinates in definitive plumage (c.f. Rohwer, 1978). Although predefinitively and definitively plumaged males interact at about the same rate as the latter do with each other (Table 3 ), the interactions (Table 4) tend to be the less costly ones. Thus, costs of membership in the group and presence at the court should be lower for predefinitive males than for older ones.

Chiroxiphia linearis. - The social system of this species is somewhat different. Each court is occupied by a pair (occasionally a trio) of males, with courts loosely grouped into exploded arenas (Foster, 1977a). The males in a pair are associated throughout a breeding season and often for several years, with one dominant to the other. Rank is determined by an aggressive interaction similar to that of swallow-tails, that occurs when the association first forms. The interactions are generally dominated by older males with more definitive plumages. When a female visits a court, the males perform a cooperative display also very similar to that of the swallow-tail. The dominant male follows this with a solo display and copulation.

Males in my study area generally did not occupy a court until they were three to four years old, although "floaters" of all ages were present in the population. Floaters were often seen in twos, but the persistence of such associations is not known. Predefinitively plumaged males also were observed as single individuals at courts. During these visits, they only rarely landed on the display perch, from which the owners displaced or chased them (or any other intruders).

Because nondefinitively plumaged males do not occupy courts continuously, the likelihood of their being present at a court to display for a female, should one arrive in the absence of the court owner, is small. Thus, although males in first-year and predefinitive plumages seem physiologically and behaviorally capable of breeding, their opportunities to do so may be limited. This may explain the delays in maturation of the testes and plumage if significant costs are associated with full development.

I observed very few aggressive interactions among $C$. linearis males. Most en- counters involved males in definitive plumage, and most were contests for dominance during the formation of the male-male pair bond, or displacements of males by higherranking individuals.

\section{Enhanced Survival}

Nondefinitive plumages may enhance survival by increasing access to resources or by decreasing predation. It is not likely that nondefinitive plumages enhance access to food or shelter in Chiroxiphia. These manakins do not occupy communal roosts, and both species are highly frugivorous, tending to rely on tree species with large fruit crops (Foster, 1977b, 1985, unpubl.; McDiarmid et al., 1977). Generally, Chiroxiphia do not engage in aggressive interactions at fruit trees, even during periods of food shortage (Leck, 1969; Foster, 1987, pers. observ.). It is also unlikely that delayed plumage maturation will increase access to resources during the nonbreeding season (winter season of Rohwer and Ewald [1981], Rohwer [1983], and Rohwer et al. [1983]). Chiroxiphia are nonmigratory and occupy the same local site year round. Thus, they do not experience the significant increases in population density often faced by North American migrants to the neotropics (Terborgh, 1980). In addition, they generally interact with known individuals already "aware" of their ages and ranks.

Rohwer et al. (1980) argued that enhanced survival as a result of decreased vulnerability to predators also is inadequate to explain the evolution of predefinitive plumages, because these plumages are often more conspicuous than that of juveniles and because individuals that wear them often behave in noticeable ways. Presumably, if selection for crypsis were important, the males would wear the most subdued plumage possible and behave inconspicuously. The firstyear plumages of $C$. caudata and $C$. linearis, although of varying shades of green like the juvenile plumages, are brighter and include a contrasting red crown; nevertheless, the predefinitive plumages, are clearly more conspicuous than those of first-year males and are also less conspicuous than those of fully adult males.

Predefinitively plumaged swallow-tailed manakin males occasionally perform courtship displays, and both they and first-year 
males commonly engage in agonistic interactions and routinely "practice" elements of both types of display by themselves (Foster, 1981, unpubl.). Nevertheless, they spend most of their time perched quietly and inconspicuously in the vegetation. Longtailed manakins in predefinitive plumages do not occupy courts continuously, and generally use inconspicuous perches rather than the display perch. The birds I watched only occasionally performed conspicuous displays, but they did vocalize regularly. Thus, male Chiroxiphia in predefinitive plumages generally are considerably less active and obvious than adult males.

These observations suggest that selection for crypsis may have been an important factor in the evolution of delayed plumage maturation in Chiroxiphia males. Birds should remain as cryptic as possible commensurate with other activities. This situation is similar to that proposed in the cryptic-breeder hypothesis (Proctor-Gray and Holmes, 1981). Young males, unable to dominate older individuals regardless of plumage state, do not benefit from wearing a bright feather cover, particularly if females select mates using criteria other than plumage characteristics. On the other hand, a bright plumage increases their conspicuousness to predators and the costliness of their interactions with older males.

Since rank is determined by means of male-male displays, with dominance apparently related to age and or experience, one may ask why males are brightly colored at all. One assumes, that as young males mature and become more experienced, benefits of bright plumage outweigh costs. Color pattern may indicate male prowess, minimizing the need for continued, extensive male-male interaction. If so, males would be expected to exhibit intermediate plumage stages rather than wear the first-year plumage for several years so as to exert their dominance over younger males, even though the intermediate plumages are more conspicuous than the first-year. In each instance, definitiveness of the plumage should be consonant with the experience and abilities of males in that age class (Kodric-Brown and Brown, 1984). Males who "cheat" by assuming a plumage more advanced than that of their age-class would be at a disadvantage in interactions with males of the older class (Rohwer, 1977), although they could benefit in interactions with birds of the same age. The definitive characteristics of a predefinitive plumage may also serve as releasers leading to interactions with other males (but, as indicated above for C. caudata, less costly ones) and females (Selander, 1965). Such interactions could serve as learning experiences, enhancing the future success of young males.

\section{Heterochrony and Neoteny}

In order to evaluate the development of the plumage and testes of the two Chiroxiphia species with regard to neoteny, it is necessary to define as clearly as possible what the primitive attributes of manakins may have been and the developmental sequence through which various derived forms may have passed, to establish that the nondefinitive plumages represent the retention of juvenile, rather than female, plumage characteristics. The family Pipridae, which includes 51 species of chiefly neotropical birds, is characterized by complex social systems, extreme sexual dichromatism with brightly colored males, performance by males of elaborate courtship displays for females, and emancipation of males from nestrelated duties. Snow (1975) considered these characters to be highly specialized. Presumed primitive members of the family are monochromatic, with males dispersed through the habitat rather than clumped on arenas.

Among the groups most closely related to the manakins are the tyrannid flycatchers (Ames, 1971; Snow, 1975; McKitrick, 1985; Sibley and Ahlquist, 1985; W. E. Lanyon, pers. comm.), which can be used as an outgroup for assessment of primitive characteristics of the piprids. The Tyrannidae is a diverse assemblage of nearly 400 species, most of which are sexually monochromatic (Verner and Willson, 1969; Meyer de Schauensee, 1970). For example, of 315 species described by Meyer de Schauensee (1970), 274 (ca. 87\%) are monochromatic, and 24 (ca. $7.6 \%$ ) are slightly sexually dichromatic (e.g., presence or absence of a 
contrasting crown patch); only 17 (ca. 5.4\%) are extensively dichromatic. To my knowledge, no predefinitive plumages have been reported for the dichromatic species. Males acquire the definitive plumage and, presumably, reach sexual maturity during their first year. As far as is known, most species of flycatchers are monogamous. It is likely, therefore, that the manakin ancestor was sexually monochromatic or exhibited only slight dichromatism; extensive plumage dichromatism would be a derived state, and delayed maturation, with the addition of one or more predefinitive stages, even more derived. Contra Lawton and Lawton (1986), I would argue that predefinitive plumage stages in manakins evolved in conjunction with derived promiscuous lek mating systems, and that they were insinuated between present-day adult and first-year plumage stages. As such, they could represent a secondarily derived recapitulation of intermediate steps in the evolution of the definitive form or a prolongation of the developmental process, with a truncation of the extent of plumage development each year. With the increased competition for mates characteristic of the derived mating systems, selection would favor the delayed maturation manifest in the predefinitive plumage stages. As noted above, however, selection should favor intermediate plumages that allow males to dominate younger rivals.

That the green color in the first-year and predefinitive plumages of caudata males represents the retention of juvenile rather than female characters may be argued on the basis of behavior and vocalizations, which, in these young males, are clearly masculine. Adult males must recognize these birds as male; the adults interact with them as they do with definitively plumaged males and not as they do with females. If young males were mimicking females, one would expect them to behave like females (or at least not like males). Hjorth (1970) noted that males of sexually dimorphic species of grouse recognize the sex of individuals on the basis of their behavior. Likewise, the sex of male American redstarts (Setophaga ruticilla) in female-like plumage is clearly evident from their behavior (Proctor-Gray and Holmes, 1981). Even Rohwer (1983) emphasized that subadult males mimicking females should be able to fool adult males for only a few hours.

On the other hand, the behavior of nondefinitively plumaged $C$. caudata, though clearly male, does differ from that of more dominant, adult males. For example, the activity level of predefinitively plumaged birds is low. They spend much of their time perched quietly and inconspicuously, low in the vegetation, and do not give the advertising call used to attract females to the court. When a female arrives, they do not attempt to court her unless more dominant males are absent. Thus, I argue that the green plumage of males is juvenile rather than female, and that its retention by sexually mature males in their first and second breeding seasons constitutes neoteny. Geist (1971) argued similarly for mountain sheep.

In $C$. linearis, the situation is more complex. Although sexual maturity (in terms of sperm production) is reached the year following hatching, maturation of the reproductive system is incomplete, as the testes do not reach full size nor are they developed over an entire reproductive season until the male is four years old (Tables 2, 5). Thus, definitive development of both the reproductive system and the plumage is probably delayed relative to time of appearance in the ancestral form and also relative to the development of the other somatic organ systems, being offset by approximately three years. This dissociation constitutes heterochrony. Whether or not it is considered neoteny is a matter of interpretation. The birds do behave as young males rather than as females in their first few breeding seasons and retain juvenile plumage features. Likewise, they are sexually mature physiologically and so fit the definition. The fact that the testes generally do not reach definitive stages of development until the fourth breeding season, however, may justify the designation of this pattern as a special type of neoteny.

Presumably, the neotenous males of both species, but especially those of $C$. caudata, are conveying misinformation not about their sex, but about their breeding capabilities. 


\section{The Evolution of Delayed Maturation}

The five hypotheses proposed to explain the evolution of delayed maturation are difficult to evaluate because their predictions are not mutually exclusive and because nondefinitive plumages may function in more than one way within a species. For example, although only the sexual-selection hypothesis ( $\mathrm{SSH})$, cryptic-breeder hypothesis $(\mathrm{CBH})$, and winter-adaptation hypothesis (WAH) explicitly postulate an enhanced survival function for predefinitive plumages, the female-mimicry hypothesis (FMH) and juvenile-mimicry hypothesis (JMH) do not preclude it from functioning in this way. Thus, demonstration of enhanced survival does not distinguish between the hypotheses. However, if one could demonstrate that mortality schedules of males in nondefinitive plumages are the same as those with definitive plumages, i.e., that survival is not enhanced, then this would refute the enhanced-survival hypotheses.

On the other hand, the WAH, JMH and FMH predict that males in definitive plumages will direct fewer or less serious attacks toward predefinitively plumaged males than they will toward each other. The SSH and $\mathrm{CBH}$, in contrast, predict equivalent levels of interaction. Interestingly, data from $C$. caudata, Icterus galbula (Flood, 1984), and Agelaius phoeniceus (Rohwer, 1978) support the former hypotheses, whereas those from $S$. ruticilla, support the latter (ProctorGray and Holmes, 1981).

With regard to reproduction, the $\mathrm{SSH}$ suggests that most predefinitively plumaged males will neither be fully sexually mature, nor breed, whereas the two mimicry hypotheses and the $\mathrm{CBH}$ suggest that all (or most) males will be fully sexually mature. In this instance, data from both $C$. caudata and $S$. ruticilla (Proctor-Gray and Holmes, 1981) support the latter hypotheses; those from Quiscalus mexicanus (Selander and Hauser, 1965) and apparently, C. linearis, support the former.

Also in contrast to the SSH, the FMH, $\mathrm{JMH}$, and $\mathrm{CBH}$ predict that reproduction of young males will be as successful as that of definitively plumaged individuals, although, perhaps, fewer of them will breed.
Data from $S$. ruticilla (Proctor-Gray and Holmes, 1981) and Icterus galbula (Flood, 1984), support this latter idea. No data available for Chiroxiphia bear on this issue. Chiroxiphia males provide no parental care. Presumably, predefinitively plumaged caudata with full sized testes produce as many viable sperm as their definitively clad counterparts. The smaller testis size of many predefinitive linearis, however, could indicate a smaller volume of sperm per ejaculate.

The important difference between the $\mathrm{JMH}$ (and even the FMH) and the CBH is not success once a male breeds, but his opportunity to do so in the first place. In territorial species (like $S$. ruticilla), males can set up territories even though the best areas are taken, expanding if necessary into marginal habitats. There they are free to try to attract and court a female. In lek-breeding forms (like $C$. caudata), in contrast, mating takes place only at arenas, which generally are located at traditional sites. This means that young, inexperienced males must compete in direct proximity with the older, more experienced individuals that dominate them and actively prevent them from courting females. Presumably by wearing a predefinitive plumage, younger males that occupy leks increase their opportunities to breed at reduced costs. This idea and the mimicry hypotheses would be refuted if the mating success of males in predefinitive plumages were no greater than that of equivalent males dyed to resemble definitive adults.

In the same way, demonstration that predefinitively plumaged males have no greater feeding success than equivalent males dyed to resemble definitively plumaged adults would refute the WAH.

Finally, the fact that predefinitively plumaged Chiroxiphia and S. ruticilla clearly behave like males significantly weakens the FMH. Their resemblance to juveniles and the tendency of Chiroxiphia to behave differently from definitively plumaged males when in their presence supports the idea of juvenile mimicry, with neoteny providing a logical mechanism for its evolution. The degree to which plumage signals sex or age could be assessed, and, thereby, the two mimicry hypotheses could be distinguished by observing the way in which 
adult males respond to females and to males dyed to resemble individuals of different sex and age.

\section{Conclusions}

In considering the evolution of delayed maturation it is necessary to distinguish between selective factors that may have promoted its initial appearance and those that presently favor its maintenance. The apparent universality of the enhanced survival function of nondefinitive plumages strongly suggests that this was the primary factor in the initial evolution of delayed maturation, given circumstances of extreme competition for mates, territories, or resources, and minimal success of young males. It is clear for Chiroxiphia and for other species as well (Rohwer et al., 1980) that intermediate plumages are duller and less conspicuous than definitive ones. Thus, regardless of other functions these plumages may serve, they must enhance survival through increased crypsis, increased access to resources, or decreased amount or level of aggression experienced. Certainly for $\mathrm{Chi}$ roxiphia, in which predefinitive plumages are exhibited by all species, but enhanced breeding may not be, the parsimonious explanation is that delayed maturation arose in the common ancestor as a means of enhancing survival.

In a contemporary context, however, enhancement of immediate mating success may be important. That male Chiroxiphia (as well as males of other species with predefinitive plumages; Proctor-Gray and Holmes, 1981; Foster, unpubl.), are physiologically capable of breeding, have access to display and copulation sites, apparently are attractive to females, and attempt to breed if the opportunity arises, support this. This contradicts the SSH, which suggests that most males will delay breeding as well as plumage maturation, and the $\mathrm{CBH}$, which proposes no active role for nondefinitive plumages in enhancing mating. In this respect the data agree with the FMH, although, as argued above, the evidence is more consistent with juvenile than with female mimicry.

Even if dichotomies between the various hypotheses can be identified, results from studies of different species are not likely to be uniform. So far, predefinitive plumages have been reported among north temperate migrant and neotropical resident species, among monogamous, polygynous, and lekmating species, and among both territorial and nonterritorial forms. In some of these species, the predefinitively plumaged males are reproductively mature; in others they are not. Given this diversity, it is unlikely that delayed plumage maturation will serve the same functions and operate in the same way in all groups, as already has been illustrated by the limited data available. Studies of closely related species with differing social and behavioral attributes will provide the best opportunities for gaining insight into the functions of this phenomenon and the different selective factors that have promoted its evolution and maintenance in so many independent avian lineages.

\section{ACKNOWLEDGMENTS}

I am indebted to the ornithology curators of the museums that loaned specimens examined in this study. G. R. Zug generously arranged for some of the histological work done by H. F. Wimer. L. A. Hayek provided advice on statistical procedures. S. Emerson and M. F. Lawton provided stimulating discussions of heterochrony and, along with B. M. Beehler, S. L. Coats, and S. Rohwer, commented critically on an early draft of the manuscript. Ing. E. Carmona of the Costa Rican Ministry of Agriculture arranged for me to work at Finca Jiménez, and A. and M. Reynaers arranged for my use of facilities at El Tirol. Collecting permits were provided by the Depto. de Pesca Continental y Vida Silvestre in Costa Rica, and through Ing. H. Moreno, Servicio Forestal Nacional, and Minister of Agriculture $\mathrm{H}$. Bertoni, in Paraguay. I thank all of these individuals and institutions for their assistance.

\section{LiterATURE CiTED}

Ames, P. L. 1971. The Morphology of the Syrinx in Passerine Birds. Peabody Mus. Nat. Hist. (Yale Univ.), New Haven, CT.

Ashmole, N. P. 1963. The regulation of numbers of tropical oceanic birds. Ibis 103b:458-473.

Ewald, P. W., AND S. Rohwer. 1980. Age, colouration and dominance in non-breeding humming- 
birds, a test of the asymmetry hypothesis. Behav. Ecol. Sociobiol. 7:273-279.

FLOOD, N. J. 1984. Adaptive significance of delayed plumage maturation in male northern orioles. Evolution 38:267-279.

Foster, M. S. 1976. Nesting biology of the longtailed manakin. Wilson Bull. 88:400-420.

—. 1977a. Odd couples in manakins: A study of social organization and cooperative breeding in Chiroxiphia linearis. Amer. Natur. 11:845-853.

- $1977 \mathrm{~b}$. Ecological and nutritional effects of food scarcity on a tropical frugivorous bird and its fruit source. Ecology 58:73-85.

- 1981. Cooperative behavior and social organization of the swallow-tailed manakin (Chiroxiphia caudata). Behav. Ecol. Sociobiol. 9:167-177.

- 1985. Social organization and behavior of the swallow-tailed manakin, Chiroxiphia caudata. Nat. Geog. Soc. Res. Rep. 18:313-320.

- 1987. Feeding methods and efficiencies of selected avian frugivores. Condor. In press.

GeIST, V. 1971. Mountain Sheep. Univ. Chicago Press, Chicago, IL.

Gould, S. J. 1977. Ontogeny and Phylogeny. Belknap Press, Cambridge, MA.

HJORTH, I. 1970. Reproductive behavior in Tetraonidae. Viltrevy 7:181-596.

Kodric-Brown, A., AND J. H. Brown. 1984. Truth in advertising: The kinds of traits favored by sexual selection. Amer. Natur. 124:309-323.

LACK, D. 1954. The Natural Regulation of Animal Numbers. Clarendon, Oxford, U.K.

LAwTON, M. F., AND R. O. LAwTON. 1986. Heterochrony, deferred breeding, and avian sociality. Current Ornithol. 3:187-221.

LECK, C. F. 1969. Observations of birds exploiting a Central American fruit tree. Wilson Bull. 81:264269.

MCDIARMID, R. W., R. E. RICKLEFS, AND M. S. FOSTER. 1977. Dispersal of Stemmadenia donnell-smithii (Apocynaceae) by birds. Biotropica 9:9-25.

MCKITRICK, M. C. 1985. Monophyly of the Tyrannidae (Aves): Comparison of morphology and DNA. Syst. Zool. 34:35-45.

MeYer De Schiauensee, R. 1970. A Guide to the Birds of South America. Acad. Nat. Sci., Philadelphia, PA.

PAYNE, R. B. 1969. Breeding seasons and reproductive physiology of tricolored blackbirds and redwinged blackbirds. Univ. Calif. Publ. Zool. 90:1115.

Proctor-Gray, E., AND R. T. Holmes. 1981. Adaptive significance of delayed attainment of plumage in male American redstarts: Tests of two hypotheses. Evolution 35:742-751.
ROHwER, S. 1977. Status signaling in Harris' sparrows: Some experiments in deception. Behaviour 61:107-129.

- 1978. Passerine subadult plumages and the deceptive acquisition of resources: Test of a critical assumption. Condor 80:173-179.

- 1983. Testing the female mimicry hypothesis of delayed plumage maturation: A comment on Proctor-Gray and Holmes. Evolution 37:421-423.

RoHwER, S., AND P. W. EwALD. 1981. The cost of dominance and advantages of subordination in a badge signaling system. Evolution 35:441-454.

Rohwer, S., S. D. Fretwell, AND D. M. Niles. 1980. Delayed maturation in passerine plumages and the deceptive acquisition of resources. Amer. Natur. 115:400-437.

Rohwer, S., W. P. Klein, Jr., AND S. Heard. 1983. Delayed plumage maturation and the presumed prealternate molt in American redstarts. Wilson Bull. 95:199-208.

SElANDER, R. K. 1958. Age determination and molt in the boat-tailed grackle. Condor 60:355-376.

- 1965. On mating systems and sexual selection. Amer. Natur. 99:129-141.

- 1972. Sexual selection and dimorphism in birds, pp. 180-230. In B. Campbell (ed.), Sexual Selection and the Descent of Man. Aldine, Chicago, IL.

Selander, R. K., AND R. J. Hauser. 1965. Gonadal and behavioral cycles in the great-tailed grackle. Condor 67:157-182.

Sibley, C. G., AND J. E. Ahlquist. 1985. The phylogeny and classification of the New World suboscine passerine birds (Passeriformes: Oligomyodi: Tyrannides). Ornithol. Monogr. 36:396-428.

SNow, D. W. 1975. The classification of the manakins. Bull. Brit. Ornithol. Club 95:20-27.

SokAl, R. R., AND F. J. Rohlf. 1969. Biometry. Freeman, San Francisco, CA.

TerborGH, J. W. 1980. The conservation status of neotropical migrants: Present and future, pp. 2130. In A. Keast, and E. S. Morton (eds.), Migrant Birds in the Neotropics. Smithsonian Inst. Press, Wash., DC.

Verner, J., AND M. F. Willson. 1969. Mating systems, sexual dimorphism, and the role of male North American passerine birds in the nesting cycle. Ornithol. Monogr. 9:1-76.

WITTENBERGER, J. F. 1978. The evolution of mating systems in grouse. Condor 80:126-137.

Wright, P. L., AND M. H. WRIGHT. 1944. The reproductive cycle of the male red-winged blackbird. Condor 46:46-59.

Corresponding Editor: R. H. Crozier 